\title{
Evaluation of the usefulness of children's drawings and story-lines in the assessment of psychological state
}

\author{
H Perera ${ }^{1}$, K Wanigasinghe ${ }^{2}$, CDK Mudalige ${ }^{2}$, HMPP Karunaweera ${ }^{2}$, YAC Jayasinghe ${ }^{3}$, WD Neelamani ${ }^{3}$, \\ MSV Sandyanganie ${ }^{3}$, GKDCA Dambadeniya ${ }^{3}$, JMMT Chandradasa ${ }^{3}$, AMGDN Weerasekara ${ }^{3}$, EMDK \\ Ekanayake $^{3}$, KD Ranjani ${ }^{3}$
}

Sri Lanka Journal of Child Health, 2007; 36: 6-9

(Key words: children's drawings, anxiety, psychological evaluation)

\begin{abstract}
Introduction Children are known to display their thoughts and emotions in drawings and storylines. This study attempts to evaluate their clinical usefulness.

Objectives To study the correlation between psychological states assessed through drawings and storylines and that assessed medically, in inpatients with psychological problems.

Method Drawings and storylines on selected themes produced by children were assessed by nurses on 6 clinical parameters, using guidelines provided to ensure consistency. This data was compared with the medical assessments on same parameters, which was used as the "gold standard".
\end{abstract}

Results Good correlation was found in identification of mood states and emotional distress. Correlation regarding cognitive development and self esteem was less satisfactory.

Conclusions Such methods are useful subsidiary tools to medical assessments but caution in interpretation is necessary in some parameters.

\section{Introduction}

Children display their psychological functioning in drawings and play activity sometimes better than expression through verbal language. Children's drawings have been used in screening for

${ }^{1}$ Professor of Psychological Medicine, Faculty of Medicine, Colombo. ${ }^{2}$ Registrar Psychiatry, Lady Ridgeway Hospital, Colombo. ${ }^{3}$ Nursing Officer, Lady Ridgeway Hospital, Colombo.

(Received on 7 February 2006. Accepted on 20 May 2006) psychological difficulties and for therapeutic interventions. For instance, drawings are used to access thoughts and feelings about situational experiences, social relationships and cognitive development ${ }^{1,2,3}$. Such evaluations are based on use of colours, size and form of the human figures, and other contents of the drawings. The anxiety level demonstrated in drawings has been used to identify children who need sedative pre-medication before surgery ${ }^{1}$. Drawing of the family is a tool for assessment of family interactions ${ }^{4}$. In hospitalized children, fears about injury and damage and distorted body images have been displayed in their drawings ${ }^{5}$. Similarly, story lines too have been useful in identifying exacerbated fear of injury, lowered selfesteem and increased dependency needs ${ }^{5}$. In child abuse, drawings are extensively used to access traumatic memories and in treatment ${ }^{6,7}$. However, some researchers question the usefulness of children's drawings as they carry certain inherent difficulties in interpretation ${ }^{8,9,10}$.

We have routinely used structured drawings and storylines on selected themes as a component of nurses' assessment to understand the psychological status of inpatients. This study aims to evaluate the usefulness and validity of these methods as subsidiary tools to medical assessment.

\section{General Objective of the study}

To study the correlation between the findings regarding the psychological state of child inpatients obtained by nurses from drawings and story lines, with that obtained by doctors from the medical assessment.

\section{Specific Objectives of the study}

The correlation was studied in the following six specific clinical parameters viz. cognitive 
developmental level, relationship with parent /carer, mood, presence of emotional distress, self esteem and obsessional traits.

\section{Method}

It is a descriptive study. The sample consisted of consecutive admissions to a specialist child mental health inpatient unit. Children under 5 years were excluded due to difficulty in obtaining reliable information independently. The information on the 6 clinical parameters given above was identified from drawings and story lines produced by the children on selected themes. Descriptive written guidelines and training were provided to nurses to ensure consistency in evaluation. In addition, each recording of data was done on agreement by 2 nurses to improve reliability. The participating nurses had over 3 years of experience in working in the inpatient unit. The doctors used their medical assessment to record the data on the same clinical parameters, which was used as the "gold standard" for comparison with that by the nurses. The 2 assessments were independent and blind from each other. The medical assessment was jointly carried out by a consultant psychiatrist and postgraduate doctors in their final year of training. A structured format was used to record all data. Ethical clearance was obtained from the Ethical Review Committee, Lady Ridgeway Hospital, Colombo.

Guidelines to assessment of drawings and storylines for the nurses

$>$ Cognitive developmental level The nurses made an estimation based on the known drawing skills present in a child that is appropriate to a given age.

$>$ Relationship with parent/carer A specific drawing format was used where the child could indicate the persons favoured and felt close to by the child and those who were not.

$>$ Mood This estimation was made using a specific drawing format where colours used, items included in the drawing and the motivation and interest shown were all used to assess the mood. Additional information was obtained from a storyline created by the child based on the theme "My Favourite Animal".

$>$ Presence of emotional distress This estimation is based on the storyline created by the child on "My Favourite Animal".
Self esteem This estimation is based on a format similar to that used in assessment of emotional distress.

$>$ Obsessional traits This estimation is based on the care taken in drawing and completing it, and how any errors made in the process were handled by the child.

\section{Results}

Study sample included 62 children aged 5 to 12 years. Mean age was 9.88 years. 41 (64.4\%) were females. $57(88.9 \%)$ children were living with their parents and $6(9.5 \%)$ were living with relatives. One child $(1.6 \%)$ came from a Children's Home. Comparison of medical and nursing identification of clinical parameters in the children is shown in Table 1.

\section{Discussion}

The identification of the mood state and emotional distress through drawings correlated best with that by medical assessment. Correlation on social relationships and obsessional traits were also significant at 0.005 levels. In comparison, correlation on cognitive development level was less satisfactory. Though drawings are frequently used to assess development of conceptual abilities in children, scientific reliability is found to be modest ${ }^{6}$. Contrary to previous studies ${ }^{5,6}$, estimation of self esteem by drawings was least useful.

Available publications on the use of drawings in medical and nursing practice are relatively few. Hence comparison was difficult. However, concerns about scoring items and person bias in assessment of emotion $^{1,8,10}$ were overcome in our study by the use of guidelines for rating and comparison with clinical standards. Use of a control group may have further validated the study.

\section{Clinical relevance}

This study shows where drawings and storylines can contribute to clinical assessment and decision making and where caution in interpretation should be exercised. Such assessment can be made use of in a variety of medical settings to monitor mental health status of children. 
Table 1

Comparison of medical and nursing identification of clinical parameters in the children

\begin{tabular}{|c|c|c|c|c|}
\hline Assessment Parameter & $\begin{array}{l}\text { Identification by } \\
\text { Doctors N (\%) }\end{array}$ & $\begin{array}{l}\text { Identification by } \\
\text { Nurses N (\%) }\end{array}$ & $\begin{array}{l}\text { Pearson's } \\
\text { correlation }\end{array}$ & $\boldsymbol{P}$ \\
\hline $\begin{array}{l}\text { 1. } \frac{\text { Cognitive }}{\text { Development level }} \\
\text { a. Below average } \\
\text { b. Average } \\
\text { c. Above average } \\
\text { 2. Relationship with } \\
\text { ad Sarents / carer } \\
\text { b. Not satisfactory } \\
\text { 3. Mood } \\
\text { a. Depressed } \\
\text { b. Angry / hostile } \\
\text { c. Normal } \\
\text { 4. Emotional distress } \\
\text { a. Present } \\
\text { c. Absent } \\
\text { 5. Self esteem } \\
\text { a. Poor } \\
\text { b. Good } \\
\text { 6. Obsessional traits } \\
\text { a. Present } \\
\text { b. Not present }\end{array}$ & $\begin{array}{l}22(35.4) \\
07(11.3) \\
33(53.2) \\
48(77.4) \\
14(22.6)\end{array}$ & $\begin{array}{l}46(74.2) \\
16(25.8) \\
27(43.5) \\
04(06.4) \\
31(50.0) \\
52(83.9) \\
10(16.1)\end{array}$ & 0.299 & 0.019 \\
\hline
\end{tabular}

\section{References}

1. Puura A, Puura K, Rorarius M, Annila P, Viitanen H, Baer G. Children's drawings as a measure of anxiety level: a clinical pilot study. Pediatric Anesthesia 2005; 15: $190-3$

2. Burkitt E, Davis A. Children's colour choices for completing drawings of affectively characterized topics. Journal of Child Psychology and Psychiatry 2003; 44: 445-55.

3. Fox TJ, Thomas GV. Children's drawings of an anxiety eliciting topic: effects on the size of the drawing. British Journal of Clinical Psychology 1990; 29: 71-81.

4. Bing E. The conjoint family drawing. Family Process 1970; 9: 173-94.

5. Irwin EC, Kovacs A. Analysis of children's drawings and stories. Family Process 2002; 41: 37-65.
6. Lewis M, King RA. Psychiatric assessment of infants, children and adolescents. In: Lewis M, editor. Child and Adolescent Psychiatry $3^{\text {rd }}$ ed. Baltimore: Lippincott, Williams \& Wilkins, 2002; 525-43.

7. Burgess A, Hartman CR. Children's drawings. Child Abuse and Neglect 1993; 17: 161-8.

8. Thomas GV, Jolley RP. Drawing conclusions: a reexamination of empirical and conceptual bases for psychological evaluation of children from their drawings. British Journal of Clinical Psychology 1998; 37: 127-39.

9. Jolley RP, Vulic-Prtoric A. Croatian children's experience of war is not reflected in the size and placement of emotive topics in their drawings. British Journal of Clinical Psychology 2001; 40: 107-10.

10. Carroll MK, Ryan-Wenger NA. School-age children's fears, anxiety, and human figure drawings. Journal of Pediatric Health Care 1999; Page 3 of 413:24-31. 